\title{
WATER RESOURCES MANAGEMENT IN TUZLA CANTON - BOSNIA AND HERZEGOVINA
}

\author{
Senada NEZIROVIĆ
}

DOI: 10.24193/AWC2021_09

\begin{abstract}
In this paper, the main sources of available drinking water and the spatial distribution of medicinal waters in the Tuzla Canton are analyzed. The focus of the paper is on the use of available drinking water and the exploitation of medicinal waters in this area. The paper describes the available quantities of drinking water, water needs and potential available quantities in the municipalities of Tuzla Canton. The conducted research indicates a lack of drinking water in this area. In order to improve the water supply of the population with drinking water in this area, it was pointed out that longterm systemic solution to the problem of drinking water shortage must be considered. Exploitation and use of medicinal water for tourist and medical purposes is done on a smaller scale. For the adequate application of medicinal waters in the work, it was also pointed out that it is necessary to improve the material basis, which primarily refers to the accommodation facilities and medical equipment in spas. The paper presents theoretical and practical research of spatial distribution of water resources and their use. The analysis of water resources presents their economic value and proposes guidelines for further use and protection.
\end{abstract}

Key words: Tuzla Canton, water resources, management.

\section{INTRODUCTION}

Tuzla Canton was created by the constitution of the Federation of $\mathrm{BiH}$ (an agreement signed in Washington in 1994), as one of its ten cantons. It has an area of $2,652 \mathrm{~km}^{2}$, which is $10.1 \%$ of the territory of the Federation of Bosnia and Herzegovina or $5.17 \%$ of the territory of Bosnia and Herzegovina (Figure 1). It is located in the northeastern part of Bosnia and Herzegovina. Tuzla Canton has a favorable geo-traffic position, it is connected to the Pannonian Plain and the Adriatic coast. In this area live 477,278 inhabitants or $21.4 \%$ of the total population of Bosnia and Herzegovina. The average population density is 179 inhabitants per $1 \mathrm{~km}^{2}$. The Tuzla Canton includes the following municipalities: Tuzla Gradačac, Gračanica, Kladanj, Lukavac, Srebrenik, Banovići, Doboj-Istok, Kalesija, Čelić, Sapna, Teočak and Živinice. (Agency for Statistics of Bosnia and Herzegovina, 2017) The administrative, economic and cultural seat is the city of Tuzla (the third largest city

\footnotetext{
${ }^{1}$ PhD. Senada Nezirović, Associate Professor, Department of Geography, Faculty of Science, Zmaja od Bosne 33 -35, University of Sarajevo, Bosnia and Hercegovina, mail: nezirovicsenadapmf@gmail.com,mob: 0038761859399
} 
in Bosnia and Herzegovina).(http: //www.vladatk. kim.ba./o-kantonu, guide for investors TK, December, 12, 2020).

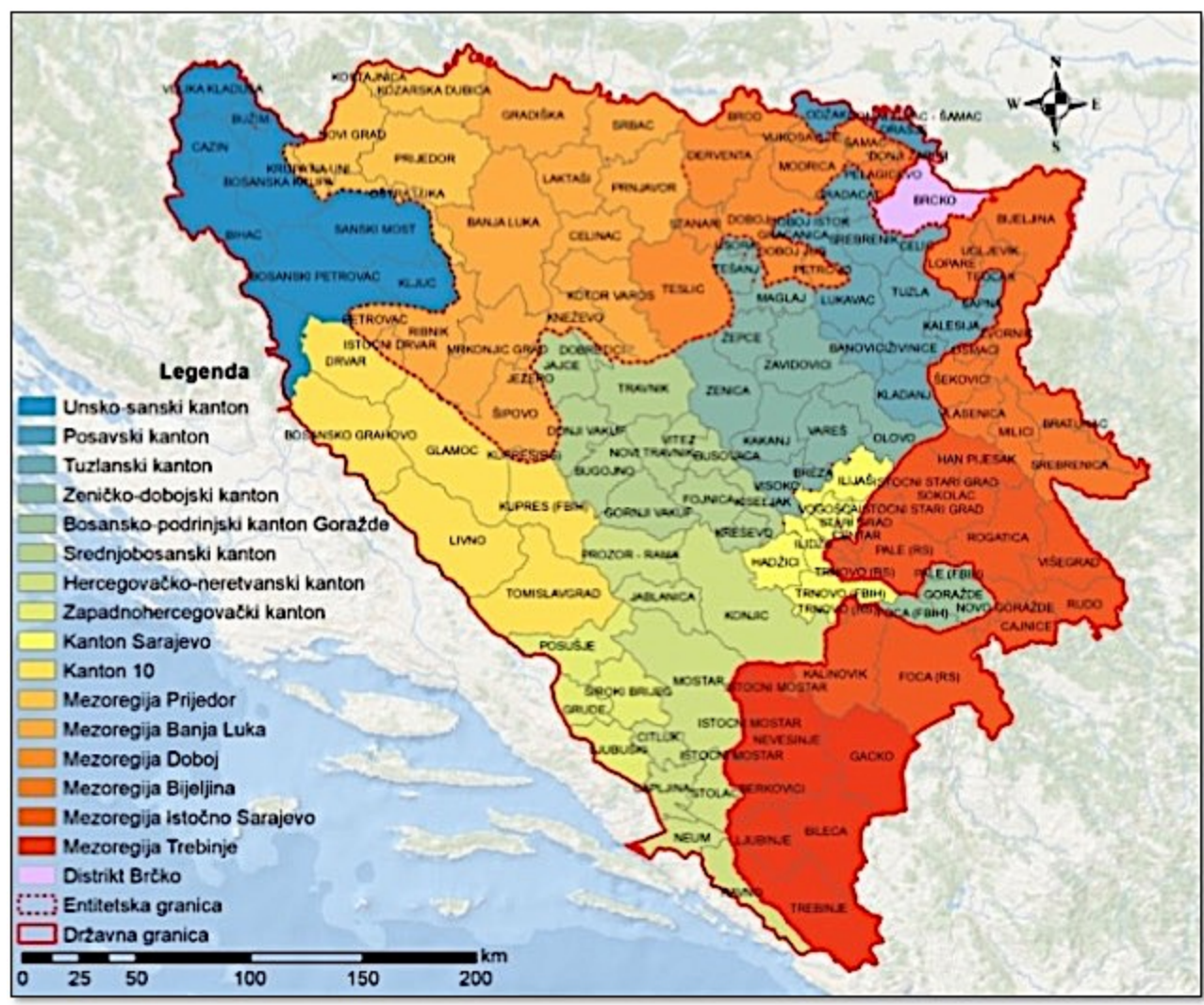

Fig. 1. Geographical position of Tuzla Canton

\section{RESEARCH METODOLOGY}

This paper presents theoretical and practical research of water resources management in the Tuzla Canton. The focus of this paper is on the use of available drinking water and the exploitation of medicinal waters in the Tuzla Canton. The research methodology required field and cabinet work. Based on field research, previous knowledge, collection of various information and documents, the author tries to point out the economic importance of water resources of Tuzla Canton, their exploitation and protection. The research methodology required the collection of data from various sources, in addition to professional literature (which is very scarce), statistical indicators, planning and strategic documents of municipalities and companies of Tuzla Canton were used. Methods used for data collection, processing and analysis are: descriptive, comparative, statistical, functional, estimation method, 
identification and valorization method. Modern GIS technology was used for the geographical presentation of the Tuzla Canton area.

\subsection{Spatial distribution of water resources in the area of TC \\ 2.1.1. River and lake waters}

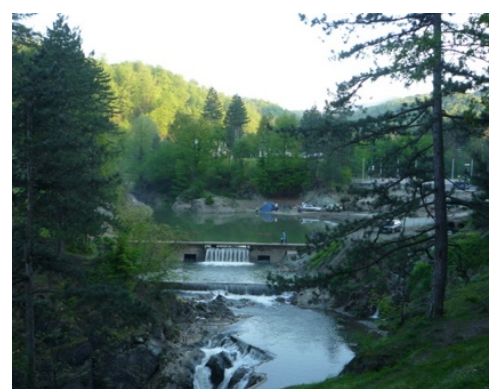

Fig. 2. Waterfalls of the river

Oskova in the area of Mačkovac

In the area of Tuzla Canton, river, lake and groundwater are represented. All watercourses in the area of Tuzla Canton belong to the Black Sea basin, and they consist of larger river flows Spreča, Tinja, Drinjača and other streams with smaller waterfalls, cascades, and rapids. The river Spreča is $137.5 \mathrm{~km}$ long, flows through the central and western part of Tuzla Canton, it is a right tributary of the river Bosna, into which it flows near Doboj. The larger tributaries of the river Spreča are: Oskova, Turija and Jala. The first major tributary of the Spreča River is the Oskova River. It is formed by the confluence of two smaller rivers, Velika Zlača and Krabanje on the mountain Konjuh and flows through the excursion area "Mačkovac." (Figure 2) Tinja springs on the southern foothills of the mountain Majevica is $69 \mathrm{~km}$ long and flows through the territory of the municipalities of Tuzla and Srebrenik. Drinjača springs on the mountain Konjuh, is $77 \mathrm{~km}$ long and flows into the river Drina. The main larger tributary of the Drinjača River is the Jadar

There are several reservoirs of lakes on the rivers intended for the production of electricity and water supply to the population. With the construction of hydroelectric power plants on rivers, artificial reservoirs of lakes Modrac, Sniježnica, Hazna and Vidar were created. Lake Modrac has accumulated on the river Spreča in the settlement of Modrac. The lake extends through the territory of the municipalities: Tuzla, Lukavac and Živinice. It has an area of $17 \mathrm{~km}^{2}$, is $11 \mathrm{~km}$ long, 1,600 meters wide and 17 meters deep. The accumulation is managed by the water management company "Spreča". Lake Modrac has a favorable geographical position and traffic accessibility. With the construction of the Hazna Dam in 1967, Lake Hazna, with a volume of $800,000 \mathrm{~m} 800$ of water, was accumulated. The surface of the lake is 1 $\mathrm{km}^{2}$, depth up to 10 meters. With the construction of the Vidar dam in 1971, the Vidar lake basin was accumulated, with a volume of 3 million $\mathrm{m}^{3}$. The surface of the lake with the surrounding protection zone is $7 \mathrm{~km}^{2}$, the maximum depth is 13 meters. Lakes Hazna and Vidar are located next to the spa Ilidža, in the immediate vicinity of the city center and represent significant tourist resources of the municipality of Gradačac. With the construction of TPP Ugljevik, there was a need for a larger amount of water, so by building a dam on the river Rastošnica, Lake Sniježnica was accumulated. The lake is located at the northeastern foot of the mountain Majevica and belongs to the territory of the municipality of Teočak. Artificial reservoirs of lakes represent important hydrographic facilities, except for the needs of the 
population, the water from the reservoirs is used for the needs of industry, electricity production, agriculture and tourism. (Nezirović, 2018)

\subsubsection{Spring waters}

In the Spreča river basin there are springs that belong to the territories of the municipalities of Banovici, Živinice, Kladanj, Kalesija and Tuzla. The area southwest of Tuzla (Banovići municipality) is characterized by the existence of coal deposits in the valleys of the Lithuanian and Dragunja rivers. North and south of the coal basin are the springs Studešnica and Krabanja. The southern part of the wider catchment area of the spring in the Spreča basin belongs to the central Bosnian ore mountains, to the southwest Konjuh, to the south Smolina, and to the east and northeast Javor and Javornik. This area is hilly and mountainous and there is a watershed between the Spreča basin and the Drinjača basin, it is intersected by numerous watercourses, most of which are with occasional flow. In this zone there is a feeding area for the Stupari and Toplice springs. The eastern, southeastern and northeastern part of the wider catchment area of the spring in the Spreča basin is located in the municipalities of Kalesija, Kladanj and Sapna on the slopes of Majevica and Javornik. On the territory of Kalesija, along the Mramor stream, there is a spring "Krušik" from which water is supplied to Kalesija. On the right bank of the river Spreča near Živinice, a source of groundwater has been formed which is used for the needs of Tuzla and Živinice. Gračanica is also supplied from the Spreča basin with water exploitation at the Soko spring, as well as Doboj Istok from the Johovak spring. for water supply Steel. The area is extremely poor in water resources, and they are also largely depleted. It is estimated that with existing groundwater sources, with the expansion of some, only $30 \%$ of the population's drinking water needs can be covered. (Government of TK, 2009.)

\subsubsection{Healing waters}

Numerous deposits of healing mineral and thermal waters have been confirmed in the river banks and in the areas of the northern and southern parts of the canton. Among the known healing springs are: Slanica in Tuzla, Ilidža in Gradačac, Terme in Gračanica, Muška voda in Kladanj, Tuzlanski kiseljak in Kiseljak near Tuzla.

Tuzla salt water is exploited for the needs of: chemical industry, spa and artificial lakes. The brine was pumped from great depths at the springs: Borić, Hukalo and Trnovac and came to the wooden reservoirs with a sonovod, and then taken to further distribution by pipes. Today, the brine is distributed from the Tetima mine, located on the slopes of Majevica, $10 \mathrm{~km}$ northeast of the city of Tuzla. The first chemical analysis of Tuzla salt water was given by E. Ludwig in 1887. Analyzes performed at the Health Institute of Bosnia and Herzegovina in Sarajevo determined the medicinal properties of brine. According to the physical properties, the water has a temperature of $27^{\circ} \mathrm{C}$, it has a salty taste, the salt concentration is $33 \%$, it is odorless and the $\mathrm{pH}$ 
value is 5.5 (alkaline). According to the chemical properties, most of the cations are sodium and calcium, and of the anions: chloride, hydrocarbons and sulfates. It is included in sodium chloride waters, with a total mineralization of $267 \mathrm{mg} / 1$ and with somewhat colloidal dissolved oxides.

The thermal baths in Gradačac erupt on a small hill, in the northern part of the town of Gradačac, between Lakes Hazna and Vidar. According to research, the thermal baths are formed at the contact of Triassic limestones, conglomerates and sandstones at the intersection of two faults. (Sarajlić, 2006). The most successful research of this water was carried out in 1979, when new spring capacities and mineral mud were discovered. Water analysis was performed at the Mining and Geological Institute and the Department of Physical Medicine and Rehabilitation, Faculty of Medicine, University of Zagreb, where the medicinal properties were determined. According to its physical properties, the water temperature is $29.5^{\circ} \mathrm{C}$, which is why it is considered a hypothermal mineral water. The water flow is $501 /$ sec and the $\mathrm{pH}$ value is 7.1 (alkaline). According to its chemical properties, it contains the most cations, sodium and calcium, and anions, hydrocarbons and sulphates, which is why it is included in sodium, calcium, bicarbonate, sulphate weakly muriatic waters, with a mineralization of $889.49 \mathrm{mg} / 1$ and some free carbon dioxide. from 56 to $64 \mathrm{mg} / 1$. Terma has low radio activity (0.397 millimicro rent), which means it cannot be classified as radio, active water. (Ilidža Spa Archive, Gradačac, 2012).

The thermal bath in Gračanica is being formed in the settlement of Šenik near Gračanica (Spatial plan for the areas of Tuzla Canton, 2005-2015, Tuzla). In the period from 1979 to 1992, intensive geological and hydrological research of thermal waters in Gračanica was carried out. Structurally investigated: exploitation drilling, quality, physico-chemical composition, indications and application of thermomineral waters in the municipality of Gračanica. (Baraković, 2004.) Gračanica waters belong to the group of thermal highly mineralized waters, with a large amount of natural carbon dioxide. Based on the results of the examination, and extensive professional-medical and clinically proven documentation, the clinical use of thermo-mineral water in Gračanica for the rehabilitation and treatment of rheumatic diseases was approved. (Šišić, 2005)

The mineral spring Muška voda is located $10 \mathrm{~km}$ from the city area of Kladanj, in the Protected Nature Landscape "Konjuh". At the end of the last century, Kladanj became famous for its healing water, which was named Muška voda. As early as the 17th century, the Turkish travel writer Čelebija called this water Muška voda-Men's Water. The capacity of the spring is 6 million liters per year. According to its mineral composition and temperature of $13^{\circ} \mathrm{C}$, it is classified as oligo-mineral cold acids. Water from this source has a positive effect on: reducing blood pressure and blood sugar, strengthens the vitality of the organism, especially in men, improves blood circulation and affects the faster excretion of water. Muška voda was bottled and 
placed on the market until the beginning of the last war in Bosnia and Herzegovina. (Archive of the Municipality of Kladanj, Mayor's Office, 2014). Tuzlaski kiseljak springs in the settlement of Kiseljak near Tuzla. The capacity of the spring is about $0.71 / \mathrm{sec}$, the water flows out of the silified serpentinite. The research was carried out up to 90 meters deep. Significantly more acidic mineral water, with more $\mathrm{CO}_{2}$, was found at the sites "Novi izvor" and "Mali kiseljak", in the immediate vicinity of "Glavni kiseljak". All sources of this mineral water belong to the group of cold mineral carbon dioxide (acid) waters of magnesium-hydro carbonate type. Most sources are still underused, and some are in the research phase.Still not sufficiently used for tourist purposes are the thermal spring in Slavinovići in Tuzla, Dubice, Boković and Dragunja (near Tuzla), Kiseljak Ljuljače in Sprečansko polje and Toplice near Živinice.

\section{RESULTS AND DISCUSSIONS}

\subsection{Water supply}

Water supply of the population in this area is done primarily from underground water resources, through springs, but part of the water is provided from the Modrac reservoir. The total length of the constructed water supply network is $335 \mathrm{~km}$ primary and $1,529 \mathrm{~km}$ secondary. Obsolescence and dysfunction of the water supply system causes water loss on average about $40 \%$. Due to which the water supply is low and uneven. The average coverage of the population with public water supply by municipalities is $49.1 \%$ (general average water supply of the population in Bosnia and Herzegovina $55 \%-60 \%$ ). In the last 6 years, there is an evident trend of network expansion, for the secondary network a total of $6.3 \%$ (average $1.05 \%$ per year), and for the primary network a total of $11.5 \%$ (average $1.9 \%$ per year). It should be noted that there is no single cadastre of sources for all municipalities in the entire canton. Out of 13 (thirteen) municipalities, only 6 (six) public water supply companies in the municipalities: Gradačac, Srebrenik, Gračanica, Banovići, Kladanj and Kalesija had concession agreements. (http://www.vladatk.kim.ba./o-kantonu, guide for TK investors, December, 12,2020) It also contributes to the lack of technological and, more recently, drinking water, but at the same time significantly leads to a deterioration of water quality. Insufficient construction, as well as obsolescence of the existing water supply network, and insufficient capacity and quality of springs, result in the fact that the average water consumption in this area per capita is about 90 liters per day (average in EU countries 100-250 liters per day). Therefore, 547 liters per day per capita should be taken from the existing water resources, which indicates very large losses in the complete process of water collection, treatment and distribution. Monitoring and quality control of drinking water in public water supply systems in these municipalities is performed by water supply operators and competent institutions. The system of continuous monitoring of drinking water quality from public fountains and springs has not been established, ie it is not performed. The total amount of water for the needs of water supply is $3,683,0032 \mathrm{~m}^{3}$ 
per year. Out of the total affected water, the distribution is made to households, about $24 \%$ of the economy, $31 \%$, and as much as $45 \%$ of the water is non-revenue amount of water, ie. losses. When it comes to capturing, bottling and distributing drinking water, little progress has been made. According to the report of the TK Concessions Commission, most concessions for the period 2017-22 were allocated for water use. (Government of TK, report on the work of the commission on concession, 2017). Therefore, in order to improve the water supply of the population with drinking water in the area of Tuzla Canton, long-term systemic solution to the problem of drinking water shortage must be considered. (Table 1)

Table 1. Water needs of Tuzla Canton municipalities in the period 2015-2025

\begin{tabular}{|c|c|c|c|c|c|c|}
\hline Municipaity & & \multicolumn{2}{|c|}{2015} & \multicolumn{2}{|r|}{2025} & deficit \\
\hline $\begin{array}{l}\text { Water supply } \\
\text { coverage }\end{array}$ & Source & $\begin{array}{l}\text { Availible } \\
1 / \text { sec }\end{array}$ & $\begin{array}{l}\text { Nedeed } \\
1 / \sec \end{array}$ & $\begin{array}{l}\text { Nedeed } \\
\text { 1/sek }\end{array}$ & $\begin{array}{l}\text { Available Qty } \\
1 / \mathrm{sec}\end{array}$ & $1 / \mathrm{sec}$ \\
\hline Banovići & Studešnica and Krabašnica & 60 & 124 & 145 & 60 & 85 \\
\hline Čelić & Brnjik Ratkovići & 20 & 34 & 44 & $20+50$ & - \\
\hline Doboj Istok & Brijesnica Klokotnica 4 wells & 40 & 29 & 35 & $40+25$ & - \\
\hline Gračanica & Soko vrelo, Škahovica well St. polje & 81 & 189 & 226 & $60+15$ & 145 \\
\hline Gradačac & Okanovići ,Domažić,Mionica & 130 & 169 & 206 & $130+50$ & 26 \\
\hline Kalesija & Krušik & 35 & 132 & 154 & 35 & 119 \\
\hline Kladanj & Starička rijeka,gluha bukvica & 20 & 61 & 74 & 20 & 54 \\
\hline Lukavac & KHK Lukavac and Spreča wells & 95 & 223 & 265 & $150+100$ & 15 \\
\hline Sapna & Sapna wells & 15 & 24 & 26 & 25 & - \\
\hline Srebrenik & Vlahulje & 40 & 154 & 191 & 40 & 151 \\
\hline Teočak & Snježnica Lake & 35 & 15 & 16 & 35 & - \\
\hline Tuzla-Živinice & Stupari,Sprečko polje, Toplice & 766 & 888 & 1036 & $600+300+100$ & 36 \\
\hline Živinice-Tuzla & Sprečko polje, Toplice & 70 & 240 & 282 & $70+100$ & 112 \\
\hline Total TK & & 1096 & 2.282 & 2.700 & 2.031 & 669 \\
\hline
\end{tabular}

Source: (Author, according to the source Spatial plan for the area of Tuzla Canton for the period 2005-2025)

\subsection{Use of medicinal waters}

Medicinal waters in this area are used for medical and tourist purposes. (Institute for Urbanism, 2016, Spatial Plan for the Tuzla Canton for the period 20052025). Tuzla's salt waters have been known since the time of Roman rule, and its official use began during the Austro-Hungarian rule. Today, Slana Banja operates under the name of the "Aqua Bristol" health resort and is stationed in the newly built Hotel Mellain, in the center of Tuzla. hydromassage cabins, salt room and pool.We also offer apart $\mathrm{T}$ "Care" for relaxation, with tense muscle fibers. The tourist offer also includes stationary accommodation.Visitors have at their disposal: rooms with living room, kitchen and bathroom. are an adjunct in the treatment of rheumatic diseases, respiratory inflammations, neuralgia, conditions after injuries or surgical procedures, stomach diseases (catarrh) and sterility. offer of Tuzla and Northeast Bosnia.The brine is used on the newly built Pannonian Lakes in Tuzla. The tourist offer of the Pannonian Lakes complex is enriched by the construction of waterfalls through which salt water flows. They are a special attraction on the complex, the salt waterfalls have the properties of an inhalation center in the open. (Archive of Panonika company, 2019). Within the waterfalls, there are five water cascades and two swimming pools, where inhalation of salt water is very beneficial: relaxation from stress, respiratory diseases, headaches and general health improvement. (Figure 
3.) The strongest prospects for the development of health tourism have Pannonian Salt lakes (expanding complex of lakes and salt waterfalls, bathing areas and beaches in the center of Tuzla) and mineral-thermal water sources (salt, sulfur and mineral waters. Development Strategy of Tuzla municipality until 2026, Volume 2: vision, strategic development goals, programs and projects Tuzla) During the summer months, the Pannonian salt lakes became the most desirable destination for the residents of Tuzla and surrounding settlements. During the hot July days, the lakes

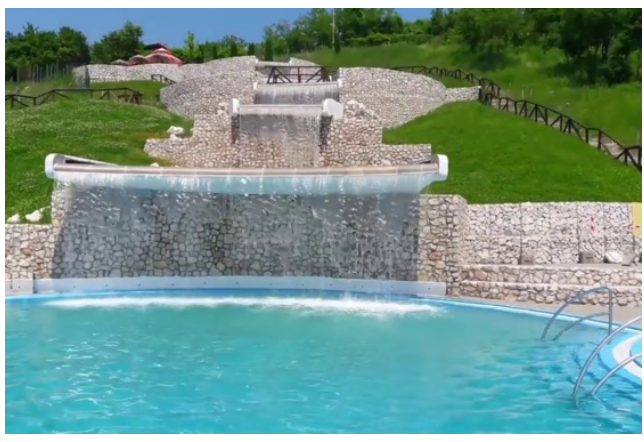

Fig. 3. Salt waterfalls on the Pannonian lakes are enjoyed daily by more than 10,000 visitors of all ages.

Thermal water in Gradačac began in 1882. (Spatial plan for the areas of TK 2005-2015.). Today's spa complex, ie. Center for Physical Medicine, Rehabilitation and Spa Treatment "Ilidža" in Gradačac was built in 1980 and is located near the source of medicinal water. The healing properties of the Ilidža thermal bath are a supplement in the treatment of chronic rheumatic diseases, metabolic diseases, post-rheumatic disorders and gynecological diseases. Modern methods of treatment and medical rehabilitation are applied in the center for physical medicine, rehabilitation and spa treatment "Ilidža". Treatment takes place in baths and pools (hydrotherapy) and mud wraps under the supervision of a professional medical team. All other physical therapies that are in use today, including acupuncture, are also used during the therapy in the spa. According to chemical analyzes, medicinal mud (peloid) contains 3.3: 1 times more minerals than water, so it is successfully used for therapeutic purposes (Archive of the Spa Hospital Ilidža, Gradačac, 2019). The offer of the Spa includes recreation in the form of: sports, walks towards the reservoirs of Lakes Hazna and Vidar and tours of cultural monuments in Gradačac. Spa "Ilidža" is a significant resource in the tourist offer of Gradačac. The temperature of the spring and the mineral healing mud give this locality an advantage and an opportunity for use for health purposes. The spa is located in the park, has an attractive ambience, trim trails, which allows patients to actively relax and enjoy the beauties of the area in addition to medical rehabilitation and spa treatment. The thermal baths in Gračanica are an untapped development opportunity. The water of the thermal spring is used in only one way today, for swimming in the outdoor pool. The healing effects of water on the human body have been proven, however, to achieve a higher level of use for medical purposes, capacities are necessary. In the following period, it is planned to build a well with a capacity of $1001 / \mathrm{sec}$ on the right side of the river Spreča, which would significantly contribute to the launch of a spa and quality valorization of this resource. (Department of Urbanism, Spatial Plan for the areas of TK 2005-2015). The thermal baths in Gračanica have real possibilities in the use of medicinal water 
for the purpose of developing health tourism. In accordance with the healing properties of the spa, tourist demand should be directed in the spa-health direction, treatment in closed tubs (pearl natural bath with plenty of $\mathrm{CO}_{2}$ dissolved in water. Possibilities for exploitation and use of healing waters in Tuzla Canton for the development of health tourism are: transformation of bathing facilities for health purposes requires additional equipment in terms of medical facilities: indoor pools, cabinet relaxation, fitness and wellness, a combination of clinical medication and balneo climate therapy strengthens the diseased organism, expansion of existing spa facilities in Gradačac construction of new in Tuzla and Gračanica provides employment opportunities medical and tourist workers, solving the issue of privatization of Terme in Gračanica, the tourist offer should be expanded with different motives (entertainment, vacation, recreation); Increase the promotion of the spa with quality publications, the Internet, as centers of health tourism and include intermediaries, agencies, tour operators.

\section{CONCLUSION}

In terms of water use and management, in addition to the population, water is used by companies, which can lead to a lack of technological and, more recently, drinking water. Water supply of commercial enterprises in the Tuzla Canton is provided in two ways: from public water supply systems and from water systems built for their own needs. Water abstraction for technological processes in the Tuzla valley is performed primarily from Lake Modrac, from where larger production plants are supplied. 135,000 inhabitants live in the wider catchment area of Lake Modrac, of which 25,000 live directly in the catchment area of the reservoir, which uses lake water. However, in order for the water from the lake to be usable for drinking and bathing, it is necessary first of all to solve the problem of wastewater, which is discharged from surface mines, industrial plants, agricultural farms and households. Lake Modrac should be restored to its former glory, when immediately after the last war in Bosnia and Herzegovina, it was the largest bathing destination in the region, where tens of thousands of bathers visited daily. We know that the quality of drinking water supply to the population through modern public water supply, is manifested in the regulation of the required amount of drinking water. The supply of drinking water to the population in this area should take precedence over all other forms of water use. At water intakes (municipal and local water supply), it is necessary to establish a system of measuring and condition of affected water quantities as well as measuring water consumption for all other types / categories of consumers (economy, other) which would enable analysis of available water, planning and rationalization of water use. In addition, there is a lack of planning documents in the field of water supply for the area of municipalities, which leads to the fact that investments for the expansion and reconstruction of the network are most often realized unplanned.From the above indicators, we can conclude that the use of water resources in the Tuzla Canton is not at a satisfactory level. Water supply problems of the population are caused by insufficient amount of water at springs during the dry season and insufficient protection of springs. Although in the next 
period it is planned to build an artificial accumulation "Mačkovac" on the river Oskova near Banovići to supply drinking water to Tuzla, Banovići, Živinice and Lukavac, hydrological, geological, hydrogeological and other research is necessary for the construction of this facility.As for medicinal waters, they are used to a lesser extent for tourist and medical purposes. For their adequate application, it is necessary to improve the material basis, which primarily refers to accommodation capacities in order to serve the purpose.

Given the importance of water, attention should be focused on: protection and polyvalent use of water resources, especially to increase food production, adequate treatment of wastewater from settlements and industry, protection from water (regulatory works) facilities, settlements and agricultural land, planned problem solving water deficit by providing additional quantities from the neighboring areas of the municipalities of Zvornik and Olovo.

\section{REFERENCES}

1. $\quad * * *$ (2017), Agency for Statistics of Bosnia and Herzegovina, Final Census Results Of Bosnia and Herzegovina, 2013

2. $\quad * * *$ (2015), Agency for Statistics of Bosnia and Herzegovina, Statistical Yearbooks

3. $\quad * * *$ (2019): Archive of Panonika company, Pannonian Lakes Complex and tourist offer of the city Tuzla, history, present and future, Tuzla

4. $\quad * * *(2014)$, Archives of the Municipality of Kladanj, office of the mayor

5. $\quad * * *$ (2017), Archive Spa Aqva Bristol, Tuzla

6. $\quad$ *** (2019) Archive of the Ilidža Spa, Gradačac

7. $\quad * * *$ (2006), Department of Urbanism, Spatial plan for the areas of Tuzla Canton 2005-2015

8. $\quad * * *$ (2012), Development Strategy of Tuzla municipality until 2026, Volume 2: vision, strategic development goals, programs and projects Tuzla

9. $* * *$ (2018): Government of Tuzla Canton, Ministry of Trade, Tourism and Transport of Tuzla Canton, Tuzla

10. $* * *$ (2017), Federal Ministry of Energy, Mining and Industry, Statistical production indicators for the field of exploration and exploitation of mineral resources

11. *** (2009), Government of Tuzla Canton, Law on Proclamation of a Part of Mount Konjuh as a Protected Landscape "Konjuh", Tuzla

12. $* * *$ (2017) Government of Tuzla Canton, Concessions Commission, Report on the work of the Concessions Commission, Tuzla, p.10.

13. $* * *$ (2016), Institute for Urbanism, Tuzla, Spatial plan for the area of Tuzla Canton for the period 2015-2025

14. http://www.vladatk.kim.ba./o-kantonu, guide for TK investors, December, 12,2020)

15. Nezirović (2018), Scientific monograph, Tourist Resources of the Northeast Bosnia Region, Faculty of Science, University of Sarajevo, Sarajevo, 188-191

16. 6. Nezirović (2012), Natural-geographical and socio-geographical determinants of tourist-geographical development of the region of Northeast Bosnia, doctoral dissertation defended on 27.11.2012 at the Faculty of Science, University of Sarajevo, 51-56

17. Sarajlić, E. (2006): Gradačac from 1945 to 1991. Alija Isaković Library, Gradačac 18. Šišić, (2005), Granički glasnik no. 20, On the medicinal properties of Gračanica Spa, Gracanica, pp.18-22. 